\title{
SIMULATION OF WATER-ROCK INTERACTION IN THE YELLOWSTONE GEOTHERMAL SYSTEM USING TOUGHREACT
}

\author{
P.F. Dobson, S. Salah, N. Spycher, and E. Sonnenthal \\ Earth Sciences Division, Lawrence Berkeley National Laboratory \\ 1 Cyclotron Road \\ Berkeley, CA 94720, USA \\ e-mail: pfdobson@lbl.gov
}

\begin{abstract}
The Yellowstone geothermal system provides an ideal opportunity to test the ability of reactive transport models to accurately simulate water-rock interaction. Previous studies of the Yellowstone geothermal system have characterized water-rock interaction through analysis of rocks and fluids obtained from both surface and downhole samples. Fluid chemistry, rock mineralogy, permeability, porosity, and thermal data obtained from the Y-8 borehole in Upper Geyser Basin were used to constrain a series of reactive transport simulations of the Yellowstone geothermal system using TOUGHREACT. Three distinct stratigraphic units were encountered in the $153.4 \mathrm{~m}$ deep Y-8 drill core: volcaniclastic sandstone, perlitic rhyolitic lava, and nonwelded pumiceous tuff. The main alteration phases identified in the Y-8 core samples include clay minerals, zeolites, silica polymorphs, adularia, and calcite. Temperatures observed in the Y-8 borehole increase with depth from sub-boiling conditions at the surface to a maximum of $169.8^{\circ} \mathrm{C}$ at a depth of $104.1 \mathrm{~m}$, with near-isothermal conditions persisting down to the well bottom. 1-D models of the Y-8 core hole were constructed to determine if TOUGHREACT could accurately predict the observed alteration mineral assemblage given the initial rock mineralogy and observed fluid chemistry and temperatures. Preliminary simulations involving the perlitic rhyolitic lava unit are consistent with the observed alteration of rhyolitic glass to form celadonite.
\end{abstract}

\section{INTRODUCTION}

Yellowstone has been the site of extensive studies of hydrothermal alteration, including the examination of samples from 13 core holes drilled by the U.S. Geological Survey (White et al., 1975). The Y-8 core, consisting of three distinct geologic units (volcaniclastic sediments, perlitic rhyolitic lava, and nonwelded pumiceous ash-flow tuff), was selected for this modeling study. We chose to model waterrock interactions occurring within the perlitic rhyolitic lava. The lava was selected for the modeling study because both the primary (igneous) and secondary (alteration) minerals of this unit have been well characterized, and dissolution/precipitation processes occur under nearly isothermal conditions. Detailed descriptions of the measured rock and water compositions and preliminary results of modeling conducted using the TOUGHREACT code are presented in the following sections.

\section{OBSERVED WATER-ROCK INTERACTION IN Y-8 CORE HOLE}

The Y-8 core hole, located in the Upper Geyser Basin of the Yellowstone geothermal system, has been the subject of a variety of water-rock studies. A general description of the stratigraphy is given by White et al. (1975). The stratigraphy consists of three main units: volcaniclastic sandstone (down to a depth of $55.2 \mathrm{~m}$ ), perlitic rhyolitic lava $(55.2-62.6 \mathrm{~m})$, and pumiceous ash-flow tuff (62.6-153.4 m). White et al. (1975) also report the results of downhole temperature and pressure surveys. Temperatures increase with depth down to a depth of $\sim 55 \mathrm{~m}$, where near-isothermal conditions $\left(160-170^{\circ} \mathrm{C}\right)$ persist down to the total depth of $153.4 \mathrm{~m}$.

Detailed mineralogical descriptions of Y-8 core samples were presented by Keith et al. (1978) and Sturchio et al. (1986). Dobson et al. (2003) characterized the permeability and porosity of Y-8 core samples and their relation to primary lithology and extent of hydrothermal alteration. Alteration has led to decreases in both permeability and porosity, and in some instances, to self-sealing resulting from the precipitation of silica.

\section{Mineralogy of Y-8 Rhyolitic Lava}

The perlitic rhyolitic lava encountered in the Y-8 core hole was correlated by Keith et al. (1978) with the $0.54 \mathrm{Ma}$ Biscuit Basin rhyolite flow. Relatively unaltered samples of this flow were observed in the neighboring Y-7 drill core; the primary mineralogy of this unit is reported in Table 1. The alteration mineralogy of this unit observed in the $\mathrm{Y}-8$ core consists of abundant celadonite (giving the cores a waxy, gray-green appearance), with lesser amounts of montmorillonite, silica polymorphs (quartz, cristobalite, chalcedony, and opal), zeolites (mordenite, clinoptilolite, and analcime), and adularia (Keith et al., 1978). Alteration is concentrated along 
hydration cracks in the perlitic glass and within veins and fractures (Figure 1).

Table 1. Mineralogy and Corresponding Thermodynamic Representation for Y-8 Rhyolite Lava.

\begin{tabular}{lcc}
\hline Mineral & Model Mineral & Abundance (\%) \\
\hline Rhyolitic glass & Rhyolitic glass & 82.3 \\
Plagioclase & Ab80An20 & 7.8 \\
Sanidine & Microcline & 2.3 \\
Quartz & Quartz & 2.1 \\
Clinopyroxene & Diopside & 2.8 \\
Fe-Ti oxides & Hematite & 2.0 \\
Orthopyroxene & Enstatite & 0.6 \\
\hline
\end{tabular}

Primary mineralogy of Y-8 perlitic rhyolitic lava from Sturchio et al. (1986).

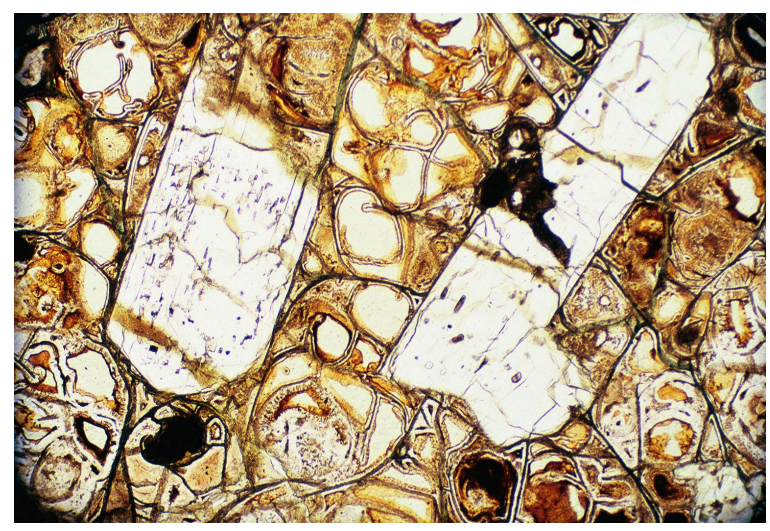

Figure 1. Photomicrograph of perlitic rhyolitic lava from $Y-8$ core at $61.37 \mathrm{~m}$ depth. Euhedral plagioclase crystals are in a glassy groundmass. Celadonite alteration is concentrated along perlitic cracks. Bottom length is $3.2 \mathrm{~mm}$.

\section{Porosity and Permeability of Y-8 Rhyolitic Lava}

Dobson et al. (2003) made a total of 6 porosity and 39 permeability measurements on perlitic rhyolitic core samples from the Y-8 well. Porosity measurements ranged from 3.4-16.2 \%, with a mean value of $10.1 \%$. All but three of the permeability values were below $0.1 \mathrm{md}$ (the detection limit of the minipermeameter used for most of the permeability measurements). The six values obtained for this unit using a conventional permeameter (with a minimum detection limit of $0.5 \mu \mathrm{d}$ ) ranged from $0.003-0.020$ md.

\section{Y-8 Water Compositions}

The compositions of water samples collected using a downhole sampler from the Y-8 well were reported by Fournier (1981), Sturchio et al. (1986), and Sturchio et al. (1989). Composite values derived from these published analyses are presented in Table 2. For comparison and use in the modeling effort, a non-thermal groundwater composition from a rhyolitic terrain (Taupo volcanic zone) is also presented.

Table 2. Initial Water Compositions.

\begin{tabular}{lcc}
\hline $\begin{array}{l}\text { Species } \\
\text { (molal) }\end{array}$ & Y-8 water & Groundwater \\
\hline $\mathrm{Cl}$ & $6.685 \mathrm{e}-03$ & $7.33 \mathrm{e}-05$ \\
$\mathrm{~F}$ & $1.474 \mathrm{e}-03$ & $1.74 \mathrm{e}-05$ \\
$\mathrm{HCO}_{3}^{-}$ & $8.407 \mathrm{e}-03$ & $6.49 \mathrm{e}-04$ \\
$\mathrm{SO}_{4}^{-2}$ & $1.561 \mathrm{e}-04$ & $3.23 \mathrm{e}-05$ \\
$\mathrm{SiO}_{2}$ (aq.) & $4.827 \mathrm{e}-03$ & $1.05 \mathrm{e}-03$ \\
$\mathrm{AlO}_{2}^{-}$ & $5.559 \mathrm{e}-06$ & $1.11 \mathrm{e}-07$ \\
$\mathrm{Ca}^{+2}$ & $8.483 \mathrm{e}-05$ & $7.24 \mathrm{e}-05$ \\
$\mathrm{Mg}^{+2}$ & $9.052 \mathrm{e}-06$ & $5.35 \mathrm{e}-05$ \\
$\mathrm{HFeO}_{2}$ (aq.) & $5.372 \mathrm{e}-06$ & $1.79 \mathrm{e}-07$ \\
$\mathrm{~K}^{+}$ & $4.220 \mathrm{e}-04$ & $3.58 \mathrm{e}-05$ \\
$\mathrm{Na}^{+}$ & $1.618 \mathrm{e}-02$ & $4.57 \mathrm{e}-04$ \\
pH & 7.26 & 7 \\
\hline $\begin{array}{l}\text { Data for Y-8 water from Fournier (1981), Sturchio et al. } \\
\text { (1986), and Sturchio et al. (1989). }\end{array}$ \\
$\begin{array}{l}\text { groundwater from Timperley (1983). } \\
\text { Data cold }\end{array}$
\end{tabular}

\section{PRELIMINARY MODELING OF WATER- ROCK INTERACTION}

The TOUGHREACT simulator (Xu and Pruess, 2001a, b) was used for the water-rock reaction simulations. TOUGHREACT incorporates reactive chemistry and transport into the TOUGH2 code (Pruess, 1991), using a sequential iteration approach for coupling chemical transport and reaction. The fluid velocities and phase saturations are used for chemical transport simulation after solution of the flow equations. Chemical transport is solved on a component by component basis, and the resulting concentrations are substituted into the chemical reaction model. Newton-Raphson iteration is used to solve the system of chemical reaction equations on a grid-block basis. The equation-of-state module EOS3, which considers the fully coupled flow of water, air and heat, was used for all simulations. TOUGHREACT allows for the selection of either kinetic or equilibrium thermodynamics to be used for mineral dissolution and precipitation. 
In this preliminary work we did not consider changes in redox state, so all iron (both in mineral and dissolved species) is represented as ferric iron.

Thermodynamic and kinetic data from various literature sources (Spycher and Sonnenthal, 2003) were employed in the simulations. Four of the considered minerals (anhydrite, goethite, calcite, and hematite) were set to react at equilibrium with the aqueous phase. Other minerals (amorphous silica, $\alpha$ cristobalite, microcline, albite, $\mathrm{Ca}-, \mathrm{Na}-$, and $\mathrm{Mg}$ smectite, illite, quartz, rhyolitic glass, enstatite, diopside, plagioclase (Ab80An20), stellerite, heulandite, mordenite, analcime, clinoptilolite, kaolinite, fluorite, and celadonite) were set to react under kinetic constraints. The solubility constant of the glass was calculated using a modified version of the Techer et al. (2001) method (Salah et al., in prep.) and microprobe analyses of unaltered glass from the Biscuit Basin rhyolite (Sturchio et al., 1986).

Water-rock interactions were evaluated in two steps. First, the saturation states of minerals in the Y-8 geothermal fluid were computed at reservoir temperatures. This allowed us to determine which mineral phases would likely be dissolving (undersaturation) or precipitating (supersaturation). Next, a dilute groundwater composition was numerically reacted with the primary $\mathrm{Y}-8$ mineralogy at $170^{\circ} \mathrm{C}$. Using this methodology, the evolution of fluid and rock compositions with time could be evaluated and compared with the observed 'final' water and rock compositions of the Yellowstone geothermal system. Reactions with a gas phase were not considered for this preliminary work.

\section{Determination of Mineral Saturations for Y-8 Geothermal Water}

This simple model evaluated the degree of saturation in the reconstituted Y-8 water for each of the minerals considered in this study. First, the Y-8 water composition (Table 2) was speciated using a temperature of $170^{\circ} \mathrm{C}$. Then, the model was run for 1 second to preclude water-rock interaction, and log $(\mathrm{Q} / \mathrm{K})$ values of the initial minerals present in the rock as well as potential secondary phases were examined (Table 3). Rhyolitic glass and potassium feldspar are undersaturated, and thus are predicted to dissolve, while the secondary minerals calcite, albite, and celadonite are oversaturated, and predicted to precipitate from this water. The geothermal water is near equilibrium with respect to the minerals Ab80An20, quartz, illite, and fluorite. None of the zeolitic phases evaluated were supersaturated in the thermal water.
Table 3. Mineral Saturations in Y-8 Water.

\begin{tabular}{lcc}
\hline Mineral Phase & $+\log (\mathrm{Q} / \mathrm{K})$ & $-\log (\mathrm{Q} / \mathrm{K})$ \\
\hline $\begin{array}{l}\text { Rhyolitic glass } \\
\text { Ab80An20 }\end{array}$ & 0.047 & -2.808 \\
Microcline & & -0.983 \\
Quartz & 0.193 & \\
Diopside & 2.581 & \\
Hematite & 6.186 & \\
Enstatite & 0.837 & \\
Anhydrite & & -2.273 \\
Goethite & 2.439 & \\
Calcite & 0.774 & \\
Amor. silica & & -0.426 \\
$\alpha$-cristobalite & & -0.140 \\
Albite & 0.345 & \\
Ca-smectite & & -1.065 \\
Na-smectite & & -1.324 \\
Mg-smectite & & -1.004 \\
Illite & & -0.088 \\
Stellerite & & -0.225 \\
Heulandite & & -1.287 \\
Mordenite & & -1.691 \\
Analcime & & -5.707 \\
Clinoptilolite & & -1.564 \\
Kaolinite & & -1.158 \\
Fluorite & & -0.094 \\
Celadonite & & \\
\hline Primary phases & & \\
\hline & 2.323 & \\
\hline
\end{tabular}

Primary phases are highlighted in bold.

\section{Simulation of Water-Rock Interaction Using 1-D Plug Flow Model}

A plug-flow model similar to that used by Dobson et al. (2003) was employed to evaluate chemical changes in both water and rock composition resulting from water-rock interaction. For this simplified model, an isothermal $\left(170^{\circ} \mathrm{C}\right)$ 1-D plug flow model was constructed with 5 rock elements. Dilute groundwater (Table 2) was injected in the first element at a constant rate, with a correspondingly slow seepage velocity $\left(\sim 3.5 \times 10^{-8} \mathrm{~m} / \mathrm{s}\right)$ to facilitate water-rock interaction. The last rock element was assigned a large volume $\left(>10^{50} \mathrm{~m}^{3}\right)$ to act as a constant pressure boundary. The simulation was run for $1.97 \times 10^{5}$ days. While this is a relatively short time period $(539 \mathrm{y})$ on the time scale of most geothermal systems (thousands to hundreds of thousands of years), it is sufficient to permit waterrock interaction. Changes in fluid compositions and mineral abundances were monitored in the first and fourth rock blocks throughout the simulation. 


\section{Simulated changes in mineralogy}

The dominant process observed in the simulation was the dissolution of rhyolitic glass, the primary mineral constituent of the rock, with over $95 \%$ of the glass dissolved after 50,000 days (Figure 2). Other primary mineral phases undergoing dissolution include quartz, enstatite, plagioclase, hematite, microcline, and diopside (except in the first rock element).

\section{Element A11_4}

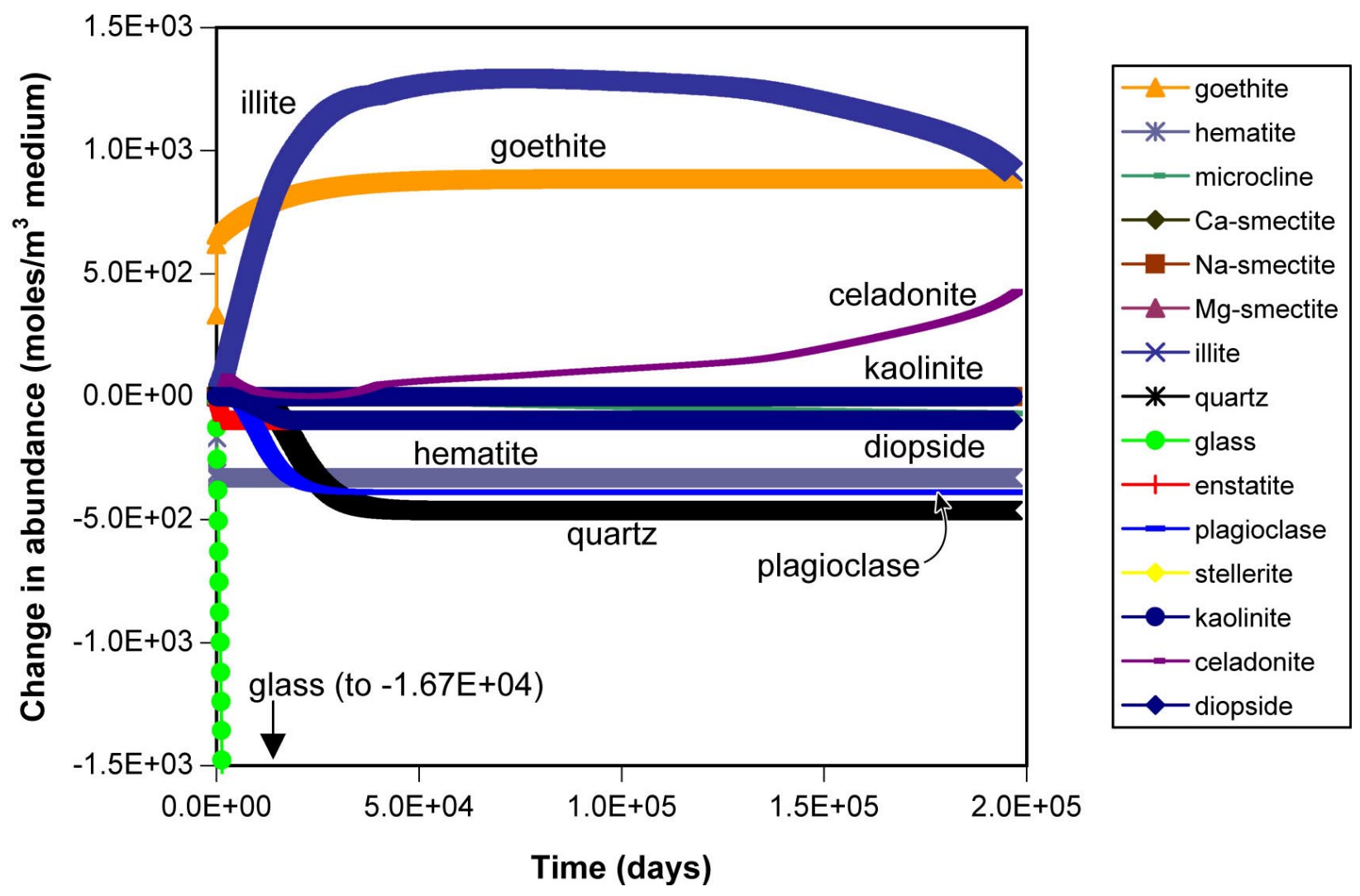

Figure 2. Simulated changes in abundance of primary and secondary minerals in the fourth plug-flow rock element. Smectite, stellerite, kaolinite, and microcline exhibit minimal change in abundance. Minerals with no measured change in abundance are not plotted.

The simulation also resulted in the precipitation of several secondary mineral phases. Illite and celadonite, the most abundant alteration phase in the Y-8 rhyolitic lavas, were the two main aluminosilicate minerals formed. Goethite, used as a proxy for iron-bearing secondary mineral phases, also precipitated during the simulation. None of the zeolites observed in the core samples (mordenite, clinoptilolite, and analcime) was produced in the simulation.

\section{Simulated changes in fluid chemistry}

Changes in fluid chemistry in the plug-flow simulation were monitored over time in the fourth element block, where the most pronounced changes in fluid chemistry were expected. Most dissolved species experience rapid initial changes in concentration, followed by the development of nearly steady-state conditions. The evolved water composition at the end of the simulation (Table 4) is very similar in many components to the initial dilute fluid (Table 2), reflecting the elevated integrated water-rock ratio for this simulation. Although some species experience increases in concentration resulting from mineral dissolution, other species, such as chloride and sodium, never approach the elevated concentrations observed in the Y-8 geothermal water. 
Table 4. Simulated Water Compositions.

\begin{tabular}{lcc}
\hline $\begin{array}{l}\text { Species } \\
\text { (molal) }\end{array}$ & $\begin{array}{c}\text { Range of simulated } \\
\text { values }\end{array}$ & $\begin{array}{c}\text { Value at end of } \\
\text { simulation }\end{array}$ \\
\hline $\mathrm{Cl}$ & $7.33 \mathrm{e}-5-7.43 \mathrm{e}-5$ & $7.33 \mathrm{e}-5$ \\
$\mathrm{~F}$ & $1.74 \mathrm{e}-5-1.76 \mathrm{e}-5$ & $1.74 \mathrm{e}-5$ \\
$\mathrm{HCO}_{3}^{-}$ & $5.57 \mathrm{e}-4-7.13 \mathrm{e}-4$ & $6.49 \mathrm{e}-4$ \\
$\mathrm{SO}_{4}^{-2}$ & $3.23 \mathrm{e}-5-3.27 \mathrm{e}-5$ & $3.23 \mathrm{e}-5$ \\
$\mathrm{SiO}_{2}$ (aq.) & $1.05 \mathrm{e}-3-4.66 \mathrm{e}-3$ & $1.11 \mathrm{e}-3$ \\
$\mathrm{AlO}_{2}^{-}$ & $1.11 \mathrm{e}-7-1.39 \mathrm{e}-4$ & $4.98 \mathrm{e}-5$ \\
$\mathrm{Ca}^{+2}$ & $5.93 \mathrm{e}-5-1.39 \mathrm{e}-4$ & $7.24 \mathrm{e}-5$ \\
$\mathrm{Mg}^{+2}$ & $4.97 \mathrm{e}-11-5.46 \mathrm{e}-5$ & $4.43 \mathrm{e}-5$ \\
$\mathrm{HFeO}_{2}$ (aq.) & $9.05 \mathrm{e}-9-1.79 \mathrm{e}-7$ & $9.16 \mathrm{e}-9$ \\
$\mathrm{~K}^{+}$ & $9.41 \mathrm{e}-6-2.37 \mathrm{e}-4$ & $3.66 \mathrm{e}-5$ \\
$\mathrm{Na}^{+}$ & $4.57 \mathrm{e}-4-9.18 \mathrm{e}-4$ & $4.57 \mathrm{e}-4$ \\
$\mathrm{pH}$ & $7.00-7.61$ & 7.07 \\
\hline
\end{tabular}

\section{DISCUSSION AND CONCLUSIONS}

This work represents a preliminary attempt to model water-rock interaction at Yellowstone. These simulations capture the dominant mineral phases undergoing dissolution and precipitation in the rhyolitic lava. However, precipitation of the zeolites clinoptilolite, mordenite, and analcime, which were observed in the Y-8 core samples, was not predicted.

There are a number of possible explanations for the discrepancies between the simulated and observed water-rock interaction. The sampled Y-8 water composition was assumed to be in equilibrium with the rhyolitic lava unit. As noted earlier, there are three distinct rock units present in the Y-8 core hole, and minerals found in the other two units may control the fluid composition. Although a downhole sampler was used to collect the samples, boiling may have altered the water samples.

A number of simplifications were made in the waterrock simulations. Stoichiometric end-member compositions were used for most of the minerals, but many of the actual observed primary and secondary mineral phases have intermediate compositions. Gas species were not included in these simulated reactions. Assumed reactive surface areas were used to simulate kinetic mineral reactions. Development of a more rigorous precipitation rate law that includes surface free energy effects as a function of particle size and surface area may improve predictions of clay and zeolite precipitation. The use of a longer plug flow model (thus decreasing the water-rock ratio) might result in more substantial changes in the evolved fluid chemistry.
Future modeling of water-rock interaction at Yellowstone can address some of the simplifications mentioned above. The ultimate goal of this work is to capture the relation between hydrothermal alteration and changes in permeability and porosity observed in the Yellowstone geothermal system.

\section{ACKNOWLEDGMENTS}

We thank Terry Keith and Tom Michalski of the USGS for facilitating the initial study of the Y-8 core. Tim Kneafsey and Jeff Hulen participated in the characterization of the Y-8 core samples. John Apps was the primary developer of the mineral thermodynamic database employed in this study. Stefan Finsterle provided helpful comments through his review of this manuscript, and Diana Swantek provided assistance with the illustrations. This work was supported by the Director, Office of Civilian Radioactive Waste Management, U.S. Department of Energy, through Memoradum Purchase Order EA9013MC5X between Bechtel SAIC Company, LLC, and the Ernest Orlando Lawrence Berkeley National Laboratory (Berkeley Lab). The support is provided to Berkeley Lab through the U.S. Department of Energy Contract DE-AC03-76SF00098.

\section{REFERENCES}

Dobson, P.F., T.J. Kneafsey, J. Hulen, and A. Simmons, Porosity, permeability, and fluid flow in the Yellowstone geothermal system, Wyoming, Jour. Volcan. Geotherm. Res., 123, 313-324, 2003.

Dobson, P.F., T.J. Kneafsey, E.L. Sonnenthal, N. Spycher, and J.A. Apps, Experimental and numerical simulation of dissolution and precipitation: implications for fracture sealing at Yucca Mountain, Nevada, J. Contam. Hydrol., 62-63, 459-476, 2003.

Fournier, R.O., Application of water geochemistry to geothermal exploration and reservoir engineering, In: Geothermal Systems: Principles and Case Histories, eds. L. Rybach and L.J.P Muffler, John Wiley and Sons, pp. 109-143, 1981.

Keith, T.E.C, D.E. White, and M.H. Beeson, Hydrothermal alteration and self-sealing in Y-7 and Y-8 drill holes in northern part of Upper Geyser Basin, Yellowstone National Park, Wyoming, U.S. Geol. Surv. Prof. Paper 1054-A, 26 pp., 1978.

Pruess, K., TOUGH2-a general-purpose numerical simulator for multiphase fluid and heat flow. Rep. LBL-29400, Lawrence Berkeley National Laboratory, Berkeley, CA, 1991. 
Salah, S., N. Spycher, E. Sonnenthal, and J. Apps, Glass/tuff alteration mechanisms and plug-flow reactor simulations (in prep.)

Spycher, N., and E. Sonnenthal,. Drift-scale coupled processes (DST and THC seepage) models, MDLNBS-HS-000001 REV02 ICN00. Bechtel SAIC Company (BSC), Las Vegas, NV, 2003.

Sturchio, N.C., K. Muehlenbachs, and M.G. Seitz, Element redistribution during hydrothermal alteration of rhyolite in an active geothermal system: Yellowstone drill cores Y-7 and Y-8, Geochim. Cosmochim. Acta, 50, 1619-1631, 1986.

Sturchio, N.C., J.K. Bohlke, and C.M. Binz, Radiumthorium disequilibrium and zeolite-water ion exchange in a Yellowstone hydrothermal environment, Geochim. Cosmochim. Acta, 53, 1025-1034, 1989.
Techer, I., T. Advocat, J. Lancelot, and J.-M. Liotard, Dissolution kinetics of basaltic glasses: control by solution chemistry and protective effect of the alteration film, Chem. Geol., 176 (1-4), 235-263, 2001.

Timperley, M.H., Phosporous in spring waters of the Taupo Volcanic Zone, North Island, New Zealand, Chem. Geol., 38, 287-306, 1983.

White, D.E., R.O. Fournier, L.J.P. Muffler, and A.H. Truesdell, Physical results of research drilling in thermal areas of Yellowstone National Park, Wyoming, U.S. Geol. Surv. Prof. Paper 892, 70 pp., 1975.

$\mathrm{Xu}, \mathrm{T}$. and K. Pruess, Modeling multiphase nonisothermal fluid flow and reactive geochemical transport in variably fractured rocks: 1 . Methodology, Am. J. Sci., 301, 16-33, 2001a

$\mathrm{Xu}, \mathrm{T}$. and K. Pruess, On fluid flow and mineral alteration in fractured caprock of magmatic hydrothermal systems, J. Geophys. Res., 106 (B2), 2121$2138,2001 b$. 